\title{
非西欧的な「第三の道」は不可能か
}

\section{斉藤 稔（法政大学）}

従来の社会主義諸国の現在の状況について、それが果たして合理的な経済システムへの転換過 程にあると言えるのだろらか。従来の社会主義体制の内部改革の試みが失敗に終わったことは明 らかである。政治的な不满を経済的な成果で吸収しようとした経済的補償は経済の非効率によっ て失敗した。これによる経済的な不満を今度は政治改革によって緩和しようとした政治的補侻の 試みむ内外の政治的抵抗によって挫折した。現在の状況は、体制内改革の失敗への批判が従来体 制の全面的否定に暴走し、あたかも現在の西側の体制が理想的な政治経済体制であるかのごとき 幻想が横行しているのであって、合理的な経済システムへの真剣な模索が行われているわけではない。

今回の報告では、特に東欧諸国の場合に、従来のソ連型社会主義への復帰でもなく、無批判な 西欧追随でもない、合理的で実現可能な「第三の道」がありうるのかどうかを検討することを課 題とした。

\section{1.「東欧」の特殊性は消隇したか}

東ドイッ（ドィッ民主共和国）は西ドイッに吸収されて消隇した。しかしながら、東ドイッの 問題は戦前からの東欧の歴史とは断絶したドイッ内部の問題であり、これを東欧地域全体に一般 化することはできない（私は以前から、東欧を論じる場合には東ドイッにはふれないできた）。 実際に、東欧のいずれの国にとっても、東ドイッのように西側に丸抱光になるといら選択はあり えないのである。

第二次大戦直後の東欧諸国が「第三の道」としての人民民主主義を選択したのは、単にソ連の 直接支配をカムフラーシュしたのではなく、一定の歷史的必然性があった。西欧に対する東欧の 近代化のおくれは、十九世紀後半に西欧への従属状態のもとでの東欧経済の奇型的発展を生じさ せ、ヨーロッパ内部の南北問題となった。両大戦間の時期には、アメリカ型のウィルソン的民主 主義も革命ロシアのボリシェウィズムもこの地域を捉えることに成功せず、結局は土着の先駆的 ファシズムの勝利からナチス・ドイッの全面的支配となった。この間に西欧は東欧に対して何ら の解決策を示すこともできなかったばかりか、ファシズムとの融和政策によってこの地域を見捨 てたのである。したがって戦後の東欧諸国が、西欧に依存することなくり連型の直輸入でもない 、東欧独自の第三の道としての人民民主主義を指向したのは当然であった。

この人民民主主義が、その後ソ連型に吸収され独自性を失っていったことは周知のとおりであ る。しかしながらこのことは直ちに「人民民主主義」の破産を意味するものではない。1989 年以来の東欧に招けるソ連型の破綻を、東欧においてはり連一辺倒か西欧一辺倒かの二者択一し かないとい5断定のもとに、今後の東欧にとっては西欧への従属と西欧的価値钼の無批判的受容 以外の選択はあり得ないとすることはあやまりであろ5。前述のような歴史的事情から、第二次 大戦後の東欧諸国にとって、西欧型の直輸入は現実に不可能であった。1990 年代において、 
西欧と異なる東欧の特殊性は完全に消隇したのであろらか。もしそらであるとすれば、まさに東 欧におけるソ連型社会主義がそのような目覚ましい成果をあげ得たことになる。そらでない限り 、東欧諸国にとっては依然として西欧とは異なる独自の発展方向を模索するという課題が残って いるのである。

政治的にはこの発展方向は、すでに「人民民主主義」において提唱され「プラ八の春」で再評 価された，複数政党制による議会制民主主義（少数意見の排除を含まない）以外にはないであろ 5。経済的には、やはり「人民民主主義」において試みられた、混合経済システムの模索が課題 であって、従来型の計画経済が失敗したからといって単純に市場経济万能の幻想に走るべきではない。

\section{2. 市場経済混合経済加}

先日ソ連のアバルキン元副首相が来日した際に、彼は「ソ連では市場経済導入そのものについ ては異論はない。そのやり方について意見が分かれているだけだ」と語った。しかし私はそらい ら見方について疑問がある。同しく「市場経済」といら言葉を使っていても、そのイメーシはお そらくかなりの相違があるはずである。その意味では、現在のいわゆる移行: (Transition)は、 それが何からの移行であるのかはある程度はっきりしていたとしても、何への移行であるのかは 事実上あいまいなままにされている。従来型の計画経済の失敗（課題として提供された目磦を達 成できなかったという意味で）から、一切の規制を排除した自由市場がすべての問題を解決して くれるだろらといら幻想にとりつかれる危険が現実に存在している。

まず第一に、ソ連および東欧諸国と西側との格差が大きく、その格差を縮小するといら課題が ある以上、政府の経済政策によって上からの格差縮小に努力する必要は大きい。この点で前アシ ア開銀副総裁の Stanley Katzは East Europe should learn from Asiaと題して、東欧諸国は 現在提案されている free market approachよりもむしろ、最近に経済的後進性を脱却して国際 競争力を強めることに成功した Asia's Newly Industrialised Countries(NICS-ーNIESでは ない）を見習うことを勧告している。アジアの NICSも日本も、産業政策の決定を市場や外国資 本に委ねることをせず、国内産業保護と輸出桨励に減税や補助金を利用し、為替レートや価格を 行政的に操作して成功した。こうした、Asia's less doctrinaire approach の方が、東欧諸国 の企業を市場により適合しやすくするだろうといらのである（Financial Times, April 2419 91)。

第二に、西側から現在提案されているような全面的な自由而場の形成などといらものは西側諸 国自体にも存在していない。西側諸国では、社会主義諸国の計画経済の一時的な成功の衝動も作 用して、すでに長年にわたって市場を公的に規制するいわゆる社会的市場経済が大勢を占めてい る。それを無視して、あたかも市場のあらゆる規制が従来型の計画経済への逆行であるかのよう に主張することは、デマゴギーである。このようなデマゴギーが、いわゆる「急進改革派」によ って利用されている。この意味で、批判派（保守派と不当に非難されている）からは、「19世紀 の資本主義（現在の資本主義ではない、露骨な搾取を特徵とする資本主義）への逆行の危険」が 指摘されているのである。これと同類の、サッチャリズムへの無批判な迎合む横行している。私 がイギリスに留学していた当時（1988年）に、ソ連から私営の病院を開設して成功している医者 がやってきて、「公的医療制度は医者を总け者にする」と発言して、サッチャー政府による医療 保険改悪にストライキで反対しているイギリスの医者や看護婦を憤慨させたことがあった。 
第三に、現在のソ連・東欧では、一方で自由選挙によって大臯受けのする政策を揭げて当選し た政治家が市場経済で何もかも良くなると宣伝して幻想をふりまき、他方で教科書的な自由市場 経済を信奉する「急進改革派」が、補償なしの大衆儀牲を伴らマネタリスト的な経済政策を強行 しようとする、ポピュリストとマネタリストの合作による生活破㐭が進行している。民主主義的 な政治制度のもとで合理的な経済政策を遂行することは、従来の政治経済制度を非難することに 比較してはるかに困難な事業であり、現代の資本主義においても解決されていない課題なのであ る。政治的民主主義と経済的合理性の最適な結合形態（それはまだ発見されていない）を求めて 真剣な模索が行われるべきであり、それは単に過去を全面的に否定したり、出来合いの形態を直 輸入したりすることでは解決されない。

\section{3. 西欧への吸収か地域的経済協力か}

ソ連・東欧の経済統合を目指したコメコンは解体した。コメコンは戦後、各国でソ連型の一国 社会主義諸国を建設するための「相互援助会議」として発足し、EEC 成立に刺激されて社会 主義諸国の地域的経済統合を目標としたが、当初から域内の後進国援助による発展水準の平準化 と全体としての効率向上とのあいだに矛盾があり、計画原理による経済統合には失敗した。市場 原理による経済統合の試み（共同市場化）む経済改革の不成功によって挫折した。さらにコメコ ンは各国の経済困難と対ソ自立の要求によって解体を余儀なくされた。この結果は、域内・域外 の後進国への援助の全面的な打ち切りとなり、東欧諸国は一路西欧に傾斜してE C 加盟を目指し 、従来の対ソ関係を精算しようとした。

ここでの問題点の第一は、東欧諸国の E Cへの加盟は果たして可能であるのか、それが東欧諸 国にとって有利であるのかといらことである。もともと工業国間の水平的統合を意図して発足し たECにとって、発展水準の格差の大きい諸国の加盟は経済統合の完成に障害となるという見解 が強い。もし加盟が認められたとしても、それは E C内の二重構造をもたらしかねない。ヨーロ ッパ内の南北問題としての現在の東西ヨーロッパ関係が $\mathrm{E} \mathrm{C}$ 加盟によって短期間に変化すること はないだろらとおもわれる。したがって第二に東欧地域での保護市場設定といら形での地域的経 済協力は不必要なのかといら問題がでてくる。ここでも、ソ連との放射状結合によるソ連への経 済的従属でもない、主として統一ドイッとの放射状結合による西欧への経済的従属でもない、「 第三の道」は果たして不可能なのが検討されるべきであろら。

さらに、ソ連・東欧の社会主義の全面的な自己否定、西欧への全面的な傾斜が世界全体特に第 三世界に与学影響を考える必要がある。ソ連・東欧の事態は、第三世界にとっては、非西欧的 発展モデルの消隇であり、第三世界に対する援助供与者と代弁者の消失であり、ひいては東西が 一体化した「南」への差別の強化の可能性である。小田 実氏は次のように書いている。「世の 負しい者、社会的弱者に対する「社会的公正」は社会主義の基本だったはずのことだ。もちろん 、党利党略がその正義の裏側にあった。しかし、それにしても、世界大に問題をひろげて言らな ら、「北」の世界の横暴に対して「南」の「第三世界」を背後から支えたのはソビエト、東ヨー ロッパの社会主義「先進国」だった。そのために自分たちは筫乏になったと東ヨーロッパ人た ちは今考えているにちがいない。．．東ヨーロッパの人たちが今ありたいと望むヨーロッパは 、西ヨーロッパがその原理の上に「社会保障国家」を形成してきた「社会民主主義」をむ非除し た、よりむき出しに資本主義的であるヨーロッパでもあれば、非ヨーロッパ世界、非西洋世界、 
「第三世界」に対する差別、僈位、支配を前提とした昔ながらの「ヨーロッパ中心主義」「西洋 中心主義」のヨーロッパでも十分仿りらるだろ5。」（毎日新聞 4 月10日夕刊） 